\title{
Electron Beam Surface Quenching of X37CrMoV51 Tool Steel Swages
}

Jiří Matlák, Pavel Doležal, Josef Zapletal, Filip Vančura, Ivo Dlouhý

Institute of Materials Science and Engineering, NETME centre, Brno University of Technology, Czech Republic

X37CrMoV51 tool steel for plastic working and heat cutting is usually used in whole volume quenched state for secondary hardness. Using high-energetic sources like electron beam or laser is possible repeated surface quenching of chosen surface localities with complicated geometry. The treatment leads to local hardness improvement which results in local wear damage decrease.

Delivered specimens were surface quenched using electron beam technology. The paper deals with influence of individual technological parameters of the treatment on final properties of treated localities. Final properties of treated surface were examined by light and electron microscopy and microhardness testing.

Keywords: electron beam, swage, X37CrMoV51, tool steel

\section{Acknowledgments}

The works have been supported by the project NETME centre plus (Lo1202), project of Ministry of Education, Youth and Sports under the "national sustainability programme”. Support of Czech Science Foundation project Nr. 13$35890 S$ is further acknowledged.

\section{References}

[1] ZENKER, R. (2009). Modern thermal electron beam processes: Research and industrial application. La Metallurgia Italiana. 2009, Aprile, s. 8.

[2] MEŠKO, J., ZRAK, A., MULCZYK, K., TOFIL, S. (2014). Microstructure Analysis of Welded Joints after Laser Welding. Manufacturing Technology. 2014, 2014(3), 355-359. ISSN 1213-2489.

[3] DIMITROV, D., APRAKOVA, M., VALKANOV, S. PETROV, P. (1998). Electron beam hardening of ion nitrided layers (1998) Vacuum, 49 (3), pp. 239-246.

[4] RADEK, N., MEŠKO, J., ZRAK, A. (2014). Technology of Laser Forming. Manufacturing Technology. 2014, 2014(3), 428-431. ISSN 1213-2489.

[5] ZENKER, R., SPIES, H. J., BUCHWALDER, A., SACHER, G. (2006). Combination of thermal surface treatment by high energy beams with thermochemical treatment and hard protective coating - State of the art (2006) "Proceedings - 15th IFHTSE - International Federation for Heat Treatment and Surface Engineering Congress 2006", pp. 214-219.

[6] IVANOV, Y. F., BESSONOV, D. A., VOROB'EV, S. V., GROMOV, V. E., IVANOV, K. V., KOLUBAEVA, Y. A., TSELLERMAER, V. Y. (2013). On the fatigue strength of grade 20Cr13 hardened steel modified by an electron beam (2013) Journal of Surface Investigation, 7 (1), pp. 90-93.

[7] DUAN, S., QIN, C., LI, B. (2015). Microstructure and properties of semi-HSS treated by laser quenching (2015) Jinshu Rechuli/Heat Treatment of Metals, 40 (9), pp. 76-78.

[8] ZENKER, R, BUCHWALDER, A. (2010). Elektronenstrahl-Randschichtbehandlung: Inovative Technologienfür höchste industrielle Ansprüche. 2nd edition. Germany: pro-beam AG\&Co. KGaA, 2010.

[9] BREZNIČAN, M., FABIAN, P., MEŠKO, J., DRBÚL, M. (2013). The Simulation of Influence of Quenching Temperature on Properties of Bearing Rings. Manufacturing Technology. 2013, 2013(1), 20-25. ISSN 1213-2489.

[10] FRIEDEL, K. P., FELBA, J., POBOL, I. WYMYSLOWSKI, A. (1996). A systematic method for optimizing the electron beam hardening process (1996) Vacuum, 47 (11), pp. 1317-1324.

[11] VUTOVA, K., DONCHEV, V., VASSILEVA, V., MLADENOV, G. (2014). Thermal processes in electron-beam treatment of metals (2014) Metal Science and Heat Treatment, 55 (11-12), pp. 628-635.

[12] JURČI, P., KUSÝ, M., PTAČINOVÁ, J., KURACINA, V., PRIKNEROVÁ, P. (2015). Long-term Sub-zero Treatment of P/M Vanadis 6 Ledeburitic Tool Steel - a Preliminary Study. Manufacturing Technology. 2015, 2015(1), 41-47. ISSN 1213-2489.

[13] SONG, R. G., ZHANG, K., CHEN, G. N. (2003). Electron beam surface treatment. Part I: Surface hardening of AISI D3 tool steel (2003) User Modeling and User-Adapted Interaction, 69 (4), pp. 513-516.

[14] DOAN, V. T., KUSMIC, D., POSPICHAL, M. (2014). Surface Treatment Technologies for Wear Resistance Increasing of 42CrMo4 Steel. Manufacturing Technology. 2014, 2014(3), 303-307. ISSN 1213-2489. 